\title{
Epidemiology and Genotypes of Hepatitis C Virus: A First Study from Jammu (J\&K), India
}

\author{
${ }^{1}$ Monika Sharma, ${ }^{2}$ Shelly Sehgal, ${ }^{3}$ Shashi S Sudhan, ${ }^{4}$ Konika Razdan, ${ }^{5}$ Bharti Pandita, ${ }^{6}$ Mamta Sharma
}

\begin{abstract}
Background and objectives: Globally, around 200 million people are infected with hepatitis C virus (HCV). India contributes a big proportion of HCV burden with the prevalence estimated between 0.5 and $1.5 \%$. Northeastern tribal populations and areas of Punjab represent the HCV infection hotspots, while in Western and Southern parts of the country, the prevalence is lower. The distribution of HCV genotypes is highly variable. This study was particularly planned to attain knowledge of the prevalent HCV genotypes in Jammu province of Jammu and Kashmir (J\&K) state.
\end{abstract}

Materials and methods: Blood samples of patients attending the Department of Medicine, Government Medical College (GMC), Jammu and Kashmir, India, for HCV testing were subjected to serological test at Department of Microbiology, GMC, Jammu. The serum samples were tested for anti-HCV antibodies by enzyme-linked immunosorbent assay (ELISA) and positive samples were subjected to genotyping

Conclusion: Of the 396 samples tested, 33 (8.33\%) were found to be HCV positive and 23 of these were included for genotyping. Genotypes 3 and 1 were detected in this region and this was in accordance with other national studies. There is a need for larger field studies to better understand the HCV epidemiology and identify higher prevalence areas and also the distribution of genotypes of HCV. This, being a maiden study from this region, will shed light to allow apposite choice and target efforts for better management of the disease and reduce the burden of chronic liver disease due to $\mathrm{HCV}$.

Keywords: Chronic liver disease, Genotyping, Hepatitis C virus, Seroprevalence.

How to cite this article: Sharma M, Sehgal S, Sudhan SS, Razdan K, Pandita B, Sharma M. Epidemiology and Genotypes of Hepatitis C Virus: A First Study from Jammu (J\&K), India. J Gastrointest Infect 2017;7(1):9-14.

\footnotetext{
${ }^{1}$ Microbiologist, ${ }^{2}$ Fellow, ${ }^{3}$ Professor, ${ }^{4}$ Research Scientist ${ }^{5}$ Student, ${ }^{6}$ Laboratory Technician

${ }^{1,3,4,6}$ Department of Microbiology, Government Medical College Jammu, Jammu and Kashmir, India

${ }^{2}$ Centre for Molecular Biology, Central University of Jammu Jammu and Kashmir, India

${ }^{5}$ School of Biotechnology, University of Jammu, Jammu and Kashmir, India

Corresponding Author: Shashi S Sudhan, Professor, Department of Microbiology, Government Medical College, Jammu, Jammu and Kashmir, India, e-mail: drshashisharma.micro@gmail.com
}

\section{Source of support: Nil}

Conflict of interest: None

\section{INTRODUCTION}

Hepatitis $C$ virus infection is one of the major global health issues. The World Health Organization (WHO) estimates that $\mathrm{HCV}$ infects about $3 \%$ of the world's population, with 1.7 million new cases and 399,000 deaths occurring each year. ${ }^{1}$ Hepatitis $C$ virus is one of the significant causes of chronic hepatitis, cirrhosis, and hepatocellular carcinoma (HCC). About 70 to $80 \%$ of infected individuals develop chronic hepatitis C (CHC) infection, ${ }^{2}$ of which 3 to $11 \%$ develop liver cirrhosis within 20 years, along with the risk of liver failure and $\mathrm{HCC}^{3}$ and the burden of the disease is expected to increase further as the infection persists lifelong. ${ }^{4}$ The WHO reports that about 71 million people have $\mathrm{CHC}$ infection globally and majority of infected people belong to the Asian subcontinent. It has been reported that $\mathrm{HCV}$ is transmitted primarily through the parenteral route in 20 to $80 \%$ due to iatrogenic exposures (transfusion/needlestick accidents/transplantation/ dialysis of infected blood/blood products or organs/ tissues) and use and sharing of contaminated injections / equipment. Sexual and maternal-infant transmissions of hepatitis $C$ are less common. ${ }^{5}$

Hepatitis $C$ virus is an enveloped icosahedral virus of 55 to $65 \mathrm{~nm}$ size and belongs to the family Flaviviridae with about $9.6 \mathrm{~kb}$ single-stranded, positive sense ribonucleic acid (RNA) genome. ${ }^{6}$ The poor fidelity of RNAdependent-RNA-polymerase (NS5B protein) contributes to a high level of nucleotide sequence heterogeneity in the viral genome. ${ }^{7}$ Based on the sequence homology, six major $\mathrm{HCV}$ genotypes (1-6) and numerous distinct subtypes exist, e.g., $1 \mathrm{~b}, 3 \mathrm{a}$, etc. ${ }^{8}$ The distribution of $\mathrm{HCV}$ genotypes is highly variable. Genotypes 1 to 3 are distributed globally, whereas genotypes 4 and 5 are restricted to the Middle East and Africa, and genotype 6 occurs predominantly in South-East Asian countries. ${ }^{9}$ The mode of HCV transmission has an association with genotype distribution as spread of HCV subtype 1a via blood transfusion and unsafe medical practices has been documented. ${ }^{10}$

The genotypic distribution of HCV in India suggests genotype 3 to be the commonest $(61.8 \%)$, followed by genotype $1(31.2 \%)$. Genotypes 2, 4, 5, and 6 have been detected in 0.05 to $4.5 \%$ of cases. ${ }^{11}$ The seroprevalence of 


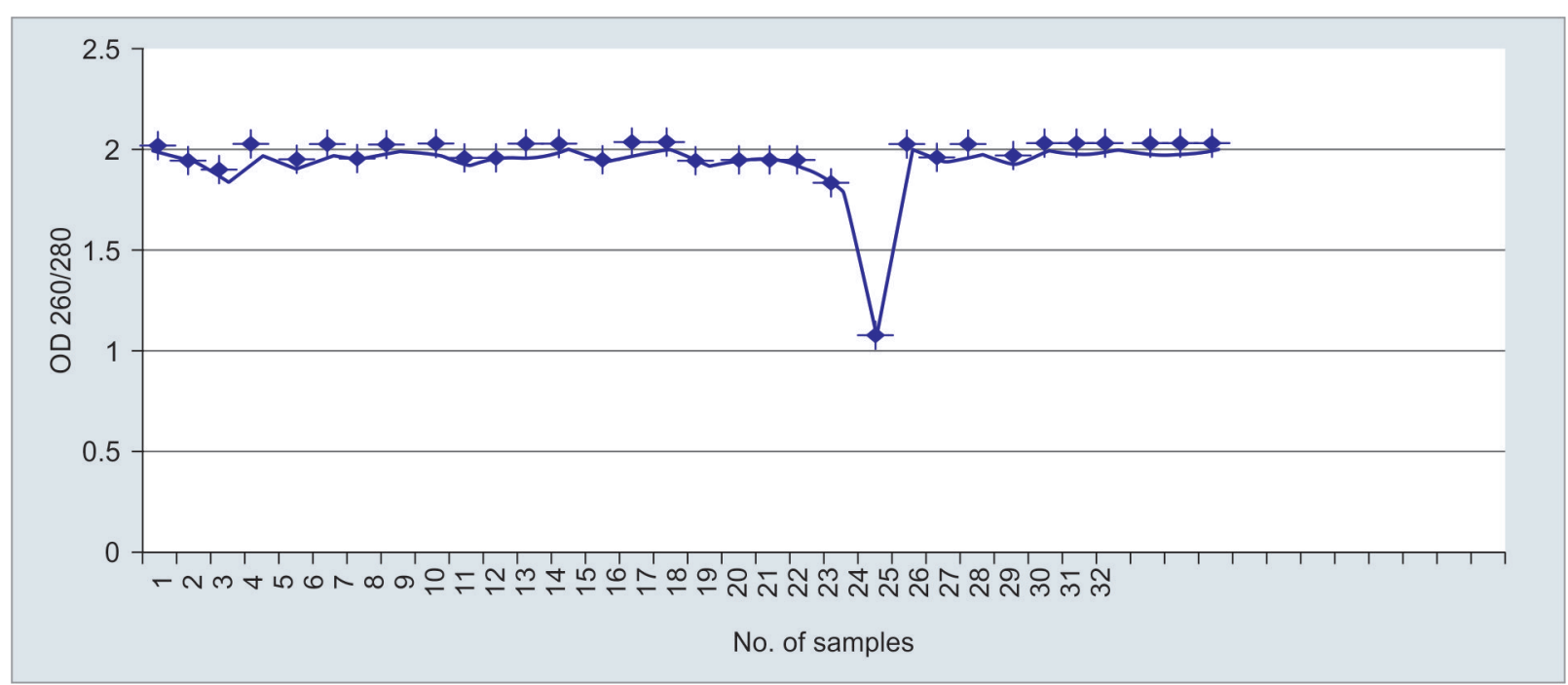

Graph 1: Quantification of RNA by nanodrop method

$\mathrm{HCV}$ in general population of India has been reported between 0.22 and $1.8 \% .{ }^{12,13}$ Although there is availability of various antiviral drug regimens, determination of $\mathrm{HCV}$ genotypes remains an important determinant to establish the course and severity of the disease process and duration and efficacy of the antiviral therapy. ${ }^{14}$ Recent studies have shown an influence on the configuration of diagnostic assays and vaccine design and recognized a key role of genotyping in orthotopic liver transplantation. Moreover, the mode of transmission of HCV in 39\% infected individuals remains unknown. Thus, genotyping may also attest to be a useful tool for tracing the source of infection. ${ }^{15}$

Jammu province of Jammu and Kashmir state has 10 districts, and this tertiary care center caters to the population from all the districts. The number of $\mathrm{HCV}$ infection is not well acknowledged in Jammu (J\&K), India. Hence, we planned this hospital-based study to determine epidemiological aspects, district-wise distribution, and $\mathrm{HCV}$ genotypes prevalence in the patients attending the tertiary care center.

\section{MATERIALS AND METHODS}

This prospective study was conducted over a period of 1 year, i.e., March 2016 to Feb 2017 at Government Medical College, Jammu (J\&K), India, a tertiary care teaching hospital, after clearance from the Institutional Ethical Committee. Blood samples were received from patients attending medical outpatient department and various wards of the hospital and processed in the Department of Microbiology. The HCV infected patients with jaundice, hepatic disease, and deranged liver function tests were included in the study, while those infected with hepatitis $B$ virus (HBV), human immunodeficiency virus, and other hepatitis viruses were excluded from the study. Serum was separated from $5 \mathrm{~mL}$ of blood collected aseptically from each patient. The serum samples were tested for anti-HCV antibodies by ELISA using SD HCV ELISA 3.0 (SD Biostandard Diagnostics Pvt. Ltd) as per manufacturer's instruction. Anti-HCV antibody-positive sera were included for HCV RNA detection and genotyping studies.

\section{HCV-RNA Extraction and Detection}

Extraction of RNA from sera was carried out manually using the protocol given by Okamoto et al ${ }^{16}$ with slight modifications. The enzyme inactivation was carried out by incubating the samples at $92^{\circ} \mathrm{C}$ for 10 minutes. Quantification of RNA was carried out by Nanodrop (Thermo Fisher) which functions by combining fiber optic technology and natural surface tension properties to capture and retain minute amounts of sample independent of traditional containment apparatus, such as cuvettes or capillaries. The RNA was successfully isolated and analyzed from only 32 sera (Graph 1).

\section{HCV Genotyping}

Samples from HCV patients were subjected to genotyping based on $\mathrm{HCV}$ core region-specific primers, using the method by Okamoto et $\mathrm{al}^{17}$ with slight modifications. The RNA was reverse-transcribed into complementary deoxyribonucleic acid using an antisense primer of the core region. For genotyping, HCV-specific amplicons were amplified using first- and second-round polymerase chain reaction, as reported by Sandres-Sauné et $\mathrm{al}^{18}$ using the genotype-specific primers. Amplicons were run and resolved on $2.5 \%$ agarose.

\section{RESULTS}

During the study period, 396 samples were tested for HCV and 33 tested positive (8.33\%) (Graph 2). The 


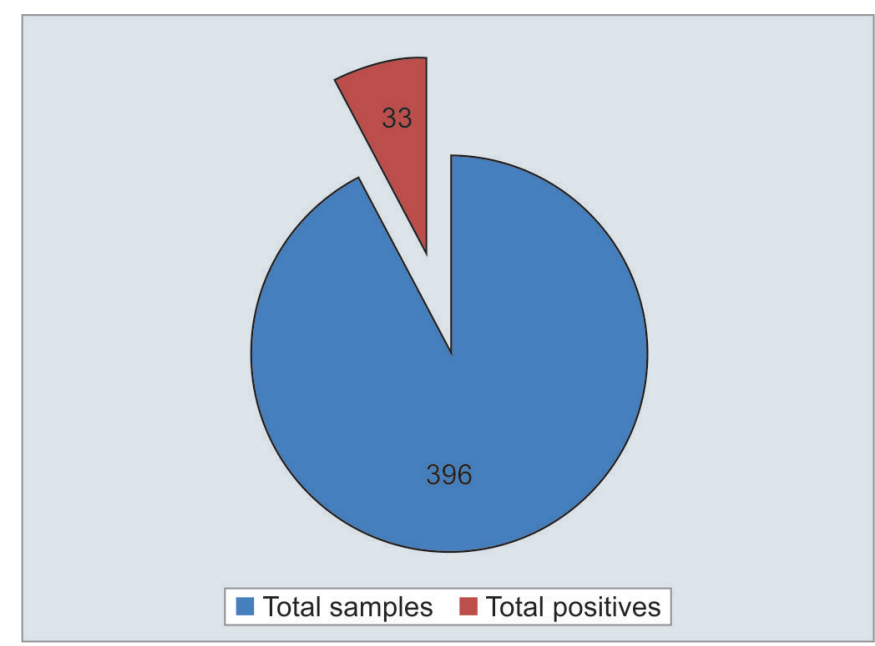

Graph 2: Total number of HCV samples tested from March 2016 to February 2017

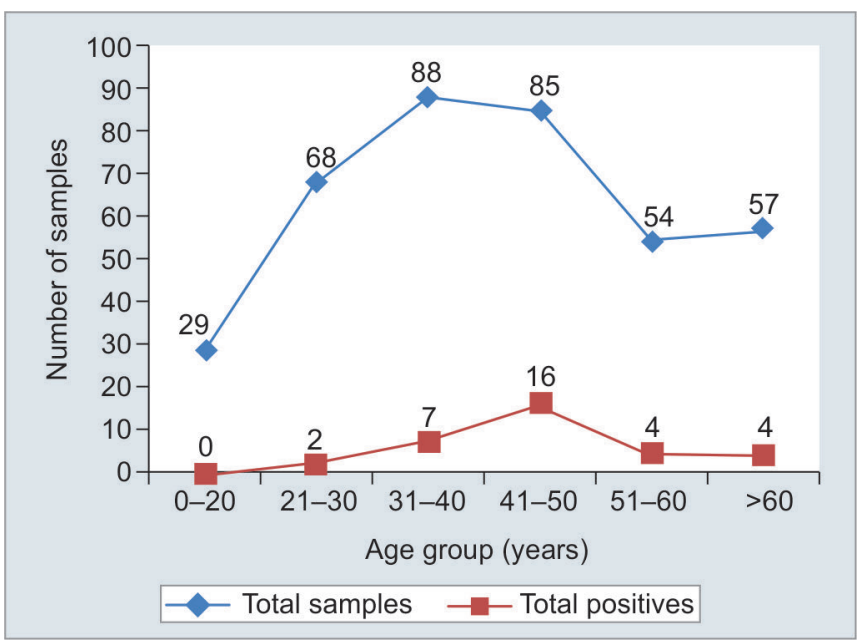

Graph 3: Age distribution of the total and positive HCV samples

genotyping of 23 samples was performed (14 genotype 3;9 genotype 1). Genotyping results of the seven samples in Figure 1 illustrate that sample number 1, 2, 4, and 6 showed approximately $260 \mathrm{bp}$ band corresponding to genotype 3, while samples 3, 5, and 7 had an amplification at $230 \mathrm{bp}$, which concluded them to be of genotype 1 . Majority of cases were reported between 41 and 50 years of age, followed by 31 to 40 years with $48.48 \%$ and $21.21 \%$ seropositivity respectively. Age groups of 51 to 60 years had $12.12 \%$ seropositivity, while 21 to 30 years and $>60$ years had an equal seropositivity of $6.06 \%$ each (Graph 3). Male preponderance was observed in gender distribution, wherein $63.63 \%(21 / 33)$ males and $36.36 \%$ $(12 / 33)$ females were observed (Graph 4). Jammu district reported the maximum number of cases $48.48 \%$, followed by Samba, Kathua, and Poonch with $12.12 \%$ seropositivity each. Udhampur and Doda reported seropositivity of $6.06 \%$ each and the district of Rajouri had

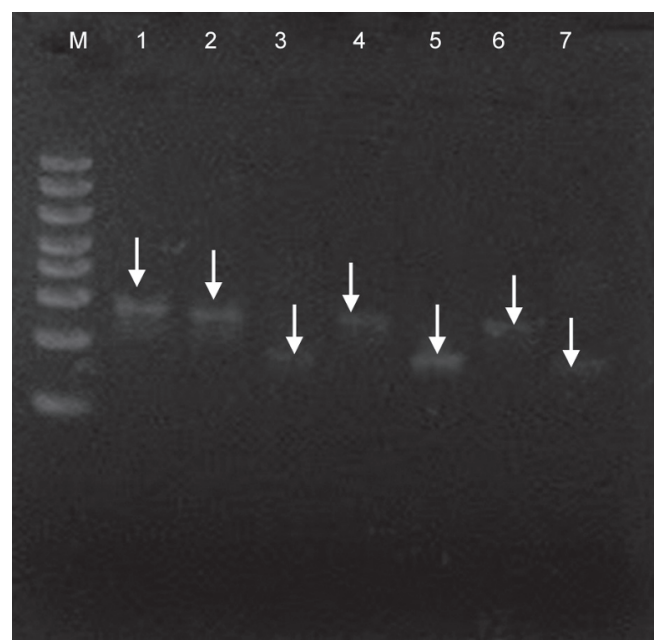

Fig. 1: Lanes 1, 2, 4, and 6 show approximately 260 bp band corresponding to genotype 3 , while wells 3,5 , and 7 show $\approx 230$ bp bands of genotype 1

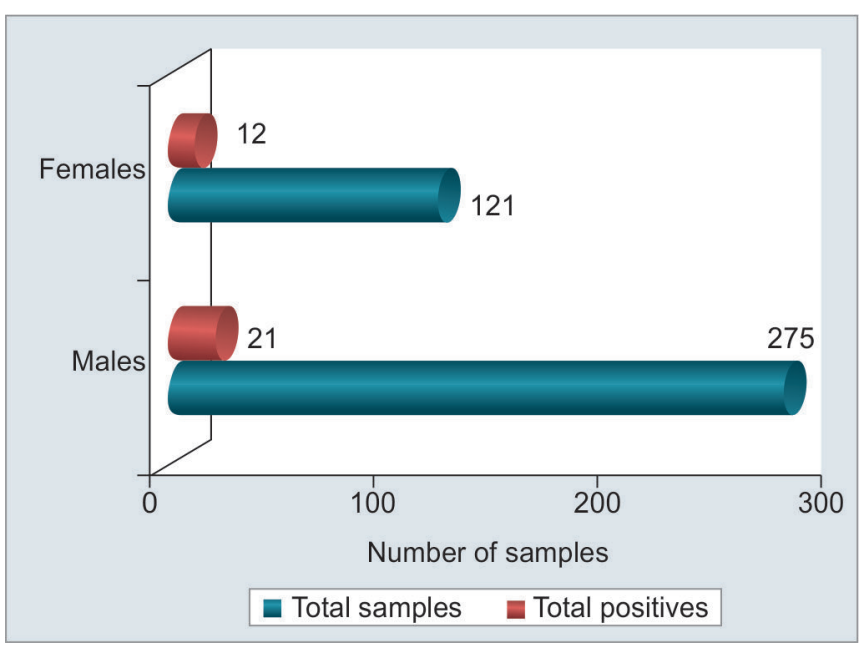

Graph 4: Gender-wise distribution of the HCV samples

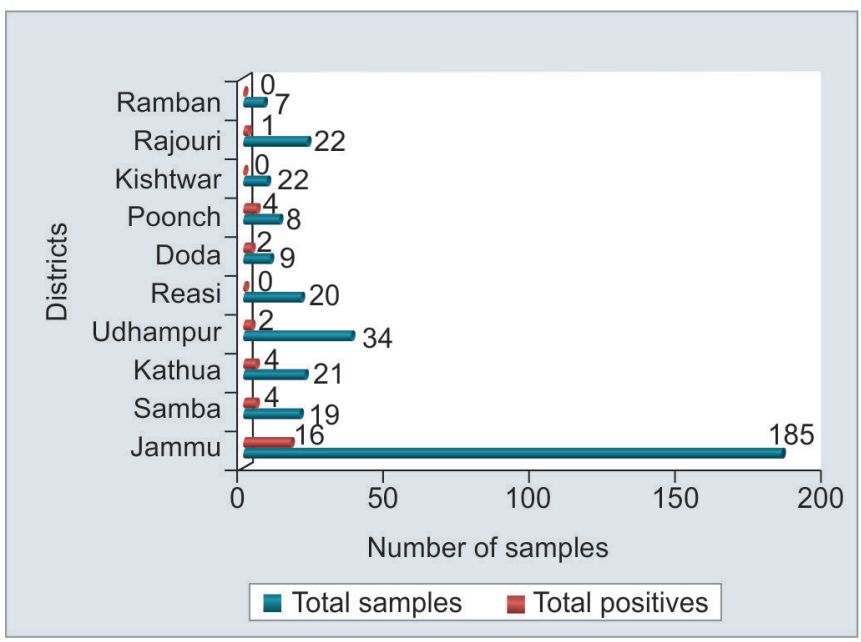

Graph 5: District-wise distribution of HCV-positive samples

seropositivity of 3.03\% (Graph 5). All the samples from Kishtwar, Ramban, and Reasi districts were reported to be negative. 


\section{DISCUSSION}

Over the last two decades, epidemiological studies have revealed the intricate patterns of infection affecting the global prevalence of this virus as well as its clinical presentation and treatment response. ${ }^{19}$ Hepatitis $\mathrm{C}$ virus infection is a preventable disease and the burden of the disease could be reduced to a significant extent if its seroprevalence is better known in the population. Therefore, this maiden study was carried out to achieve and document the baseline data of both the seroprevalence and also to determine various genotypes of $\mathrm{HCV}$ in patients attending the tertiary care center.

The current study reported a seropositivity of $8.33 \%$ in our hospital-based population, which is in concordance with the study from Delhi reporting seroprevalence of 5.5\%. ${ }^{20}$ In India, the seroprevalence of HCV varies among hospital-based populations with 1.57\% from Cuttack, ${ }^{21} 1.7 \%$ from Jaipur, ${ }^{22}$ and $4.8 \%$ reported from Puducherry. ${ }^{23}$

International studies from Mauritius, ${ }^{24}$ Ethiopia ${ }^{25}$ and Pakistan ${ }^{26}$ have reflected a seroprevalence of 5.9, 6, and $9 \%$ respectively. On the contrary, a study from Iraq documented comparatively low seroprevalence of $0.81 \%$ for the year 2013. ${ }^{27}$

Genotypes have a significant role in guiding the therapeutic, prognostic, and clinical outcome of the $\mathrm{HCV}$ infection. Chronic hepatitis $\mathrm{C}$ can be treated with antiviral therapy. Patients infected with HCV genotype 1 are treated with pegylated interferon and Ribavirin, while those infected with HCV genotype 2 or 3 have better response to interferon alpha. ${ }^{28}$ Several clinical trials advocate that pretreatment determination of HCV genotype helps in deciding the appropriate treatment regimen and duration of therapy..$^{29}$ Our study has reported the predominance of $\mathrm{HCV}$ genotype 3 followed by genotype 1 in HCV infected patients, which is in accordance with the study from Delhi. ${ }^{30}$ They further concluded that HCV genotypes 3 and 1 accounted for approximately 95\% of the HCV infection in Delhi and surrounding areas. The epidemiological patterns of HCV genotypes have variegated geographical distribution among different regions of the same country. Several studies from India have reported all the genotypes, with genotype 3 being the most common in Northern, Eastern, and Western India, ${ }^{31-33}$ whereas data from South India depicts high occurrence of genotype $1 .{ }^{34}$

Several international studies from Pakistan and Southern Asia have also documented the predominance of genotype $3 .{ }^{35}$ On the contrary, Southern and Eastern Europe, Japan, and North Africa show high prevalence of genotype 1 , while genotype 2 is common in Northern
Italy. Genotypes 4 and 5 are highly common in Arabian countries and South Africa respectively. Genotype 6 prevails in Hong Kong and Vietnam. ${ }^{36}$

In our study, male dominance was observed with seropositivity of $63.63 \%$ and is in agreement with the studies from Uttarakhand, Delhi, and Haryana. ${ }^{37,38}$ Another study from Delhi revealed the male preponderance with overall male to female ratio of $1 \cdot 5: 1{ }^{20}$ A study from Pakistan revealed $46.29 \%$ of the males affected in comparison to females. ${ }^{39}$ The male gender is most likely to indulge in risky behavior and practices, such as IV drug abuse, unprotected sex, etc., explaining the male predominance. However, Ramarokoto et $\mathrm{al}^{40}$ in their study on the seroprevalence of hepatitis $C$ in urban areas of Madagascar reported that the prevalence did not differ significantly according to gender but increased with age.

In the present study, the age group of 41 to 50 years showed the highest seropositivity of $3.28 \%$, which is in concordance with other North Indian studies. ${ }^{41,42}$ The reason behind the dominance of $\mathrm{HCV}$ in a particular age group may be due to the long asymptomatic period of hepatitis $\mathrm{C}$ infection with symptoms appearing after a long latent period. ${ }^{43}$ Adults are at higher exposure risk due to unsafe practices. ${ }^{44}$ Hepatitis $C$ virus is usually transmitted by sharing infected needles, unsafe transfusion practices, and accidental exposures.

The limitation of this study is that it is an institutionbased study, so the patients going to private sector could not be included in the study. Hence, there is an expected underreporting. Also, the serological assay fails to detect the patients in the window period.

Although the sample size is small in this hospitalbased study, but the findings throw light on the prevalent genotypes. However, more meticulous characterization of HCV subtypes needs to be done further on a greater sample size. Also, this familiarity of region and agespecific distribution of $\mathrm{HCV}$ infection is imperative for national disease prevention and control efforts, treatment, evaluating vaccination program, and also in liver transplantation. In addition, implementation of research focusing on region-specific endemicity levels is mandatory in developing countries where the burden of viral hepatitis is greater, ensuring greater prominence on innovative, safe, and cost-effective solutions.

\section{ACKNOWLEDGEMENT}

Authors would like to thank VRDL, ICMR, Department of Health Research, Ministry of Health and Family Welfare, Govt. of India for infrastructure and human resource. Dr Shelly Sehgal (coauthor) received the UGC-Women Postdoctoral fellowship. 


\section{REFERENCES}

1. WHO. Hepatitis C Fact sheet. Geneva: WHO; 2017.

2. Ray K. The global burden of viral hepatitis is increasing. Nat Rev Gastroenterol Hepatol 2016 Sep;13(9):499.

3. Dore GJ, Freeman AJ, Law M, Kaldor JM. Is severe liver disease a common outcome for people with chronic hepatitis C? J Gastroenterol Hepatol 2002 Apr;17(4):423-430.

4. Poynard T, Yuen MF, Ratziu V, Lai CL. Viral hepatitis C. Lancet 2003 Dec;36(9401):2095-2100.

5. Gower E, Estes C, Blach S, Razavi-Shearer K, Razavi H. Global epidemiology and genotype distribution of the hepatitis $\mathrm{C}$ virus infection. J Hepatol 2014 Nov;61(1 Suppl):S45-S57.

6. Noorali S, Pace DG, Bagasra O. Of lives and livers: emerging responses to the hepatitis C virus. J Infect Dev Ctries 2011 Feb;5(1):1-17.

7. Moradpour D, Penin F, Rice CM. Replication of hepatitis C virus. Nat Rev Microbiol 2007 Jun;5(6):453-463.

8. Lu L, Li C, Fu Y, Gao F, Pybus OG, Abe K, Okamoto H, Hagedorn $\mathrm{CH}$, Murphy D. Complete genomes of hepatitis $\mathrm{C}$ virus (HCV) subtypes 6c, 6l, 6o, 6p and 6q: completion of a full panel of genomes for HCV genotype 6. J Gen Virol 2007 May;88(Pt 5):1519-1525.

9. Bostan N, Mahmood T. An overview about hepatitis C: a devastating virus. Crit Rev Microbiol 2010 May;36(2):91-133.

10. Romano CM, de Carvalho-Mello IM, Jamal LF, de Melo FL, Iamarino A, Motoki M, Pinho JR, Holmes EC, Zanotto Pm; The VGDN Consortium. Social networks shape the transmission dynamics of hepatitis C virus. PLoS One 2010 Jun;5(6):e11170.

11. Satsangi S, Dhiman RK. Combating the wrath of viral hepatitis in India. Indian J Med Res 2016 Jul;144(1):1-5.

12. Narahari S, Juwle A, Basak S, Saranath D. Prevalence and geographic distribution of hepatitis $C$ virus genotypes in Indian patient cohort. Infect Genet Evol 2009 Jul;9(4): 643-645.

13. Gowri V, Chandraleka C, Vanaja R. The current seroprevalence of hepatitis $C$ virus in a tertiary care centre in Vellore, Tamil Nadu. Indian J Community Med 2012 Apr-Jun;37(2):137.

14. Ciotti M, D'Agostini C, Marrone A. Advances in the diagnosis and monitoring of hepatitis $C$ virus infection. Gastroenterol Res 2013 Oct;6(5):161-170.

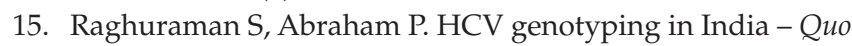
vadis? Indian J Med Res 2004 Apr;119(4):ix-xi.

16. Okamoto H, Sugiyama Y, Okada S, KKurai, Akahane Y, Sugai Y, Tanaka T, Sato K, Tsuda F, Miyakawa Y, et al. Typing hepatitis $C$ virus by polymerase chain reaction with type-specific primers: application to clinical surveys and tracing infectious sources. J Gen Virol 1992 Mar;73(Pt 3):673-679.

17. Okamoto H, Kobata $S$, Tokita H, Inoue $T$, Woodfield GD, Holland PV, Al-Knawy BA, Uzunalimoglu O, Miyakawa Y, Mayumi M. A second-generation method of genotyping hepatitis $C$ virus by the polymerase chain reaction with sense and antisense primers deduced from the core gene. J Virol Methods 1996 Mar;57(1):31-45.

18. Sandres-Sauné K, Deny P, Pasquier C, Thibaut V, Duverlie G, Izopet J. Determining hepatitis $C$ genotype by analyzing the sequence of the NS5b region. J Virol Methods 2003 May;109(2):187-193.

19. Trinks J, Gadano A, Argibay P. Evolving trends in the hepatitis $C$ virus. Molecular epidemiology studies: from the viral sequences to the human genome. Epidemiol Res Int 2012 Jan;2012:856810.
20. Rajani M, Jais M. Age-wise seroprevalence of hepatitis $C$ virus infection in clinically suspected infectious hepatitis patients attending a tertiary care hospital in Delhi. Int J Med Public Health 2014 Jan;4(1):81.

21. Mishra S, Chayani N, Sarangi G, Mallick B, Pati SB. Seroprevalence of anti HCV antibody in and around Cuttack, Orissa. Indian J Med Microbiol 2002 Jan-Mar;20(1):40-41.

22. Sharma R, Sinha P, Bachiwal R, Rishi S. Seroprevalence of anti-hepatitis $C$ virus antibodies in a hospital based population in Jaipur, Rajasthan. Indian J Community Med 2007 May;32(2):158-159.

23. Bhattacharya S, Badrinath S, Hamide A, Sujatha S. Seroprevalence of hepatitis $C$ virus in a hospital based general population in South India. Indian J Med Microbiol 2003 Jan-Mar; 21(1):43-45.

24. Schwarz TF, Dobler G, Gilch S, Jager G. Hepatitis C and arboviral antibodies in the isolated population of Mauritius and Rodrigues. J Med Virol.1994; 44: 379-383.

25. Frommel D, Tekla HR, Berhe N, Aussel L, Verdier M, Preux $\mathrm{PM}$ et al, and Denis, F. A survey of antibodies to Hepatitis C virus in Ethiopia. Am J Trop Med Hygiene. 1993; 49 : 435-439.

26. Khan MSA, Khalid M, Ayub N, Javed M. Seroprevalence and risk factors of hepatitis C virus (HCV) in Mardan, NWFP: a hospital based study. RMJ. 2004; 29(2): 57-60.

27. Alsamarai AM, Abdulrazaq G, Alobaidi AH. Seroprevalence of hepatitis $C$ virus in Iraqi population. Juniper Online J Immuno Virol 2016 Dec;1(3):1-9.

28. Sodhi JS, Parveen S, Saif R. New horizons and perspectives in the management of chronic hepatitis C. J Med Sci 2010;13(2):41-47.

29. Westbrook RH, Dusheiko G. Natural history of hepatitis C. J Hepatol 2014 Nov;61(1 Suppl):S58-S68.

30. Chakravarti A, Dogra G, Verma V, Srivastava AP. Distribution pattern of HCV genotypes and its association with viral load. Indian J Med Res 2011 Mar;133(3):326-333.

31. Das BR, Kundu B, Khanapkar R, Sahni S. Geographical distribution of hepatitis $C$ virus genotypes in India. Indian J Pathol Microbiol 2002 Jul;45(3):323-328.

32. Medhi S, Goswami B, Das AK, Singh TB, Husain SA, Sehgal A, Kar P. New insights into hepatitis $C$ virus infection in the tribal-dominant part of Northeast India. Arch Virol 2012 Nov;157(11):2083-2093.

33. Raghuraman S, Abraham P, Sridharan G, Ramakrishna BS. Hepatitis $C$ virus genotype 6 infection in India. Indian. J Gastroenterol 2005 Mar-Apr;24(2):72-75.

34. Raghuraman S, Abraham P, Sridharan G, Daniel HD, Ramakrishna BS, Shaji RV. HCV genotype 4 - an emerging threat as a cause of chronic liver disease in Indian (south) patients. J Clin Virol 2004 Dec;31(4):253-258.

35. Umer $M$, Iqbal M. Hepatitis $C$ virus prevalence and genotype distribution in Pakistan: comprehensive review of recent data. World J Gastroenterol 2016 Jan;22(4):1684-1700.

36. Esmaeilzadeh A, Erfanmanesh M, Ghasemi S, Mohammadi F. Serological assay and genotyping of hepatitis $C$ virus in infected patients in Zanjan province. Hepat Mon 2014 Sep;14(9):e17323.

37. Mittal G, Gupta P, Gupta R, Ahuja V, Mittal M, Dhar M. Seroprevalence and risk factors of hepatitis $B$ and hepatitis $C$ virus infections in Uttarakhand, India. J Clin Exp Hepatol 2013 Dec;3(4):296-300.

38. Sarma MP, Asim M, Medhi S, Bharathi T, Diwan R, Kar P. Viral genotypes and associated risk factors of 
hepatocellular carcinoma in India. Cancer Bio Med 2012 Sep;9(3):172-181.

39. Mi Ullah, F Hasan, Najmudin, MM Alam, SSZZ, MS Rana, M Nawaz, S Rehman and AA Shah. Seroprevalence of Hepatitis C Virus Infection in Kohat Division, Khyber Pakhtoonkhwa, Pakistan. Pakistan J Zool 2016;.48(6):1721-1725.

40. Ramarokoto CE, Rakotomanana F, Ratsitorahina M, Raharimanga $\mathrm{V}$, Razafindratsimandresy $\mathrm{R}$, Randremanana $\mathrm{R}$, Rakoto-Andrianarivelo M, Rousset D, Andrianaja V, Richard V, et al. Seroprevalence of hepatitis $C$ and associated risk factors in urban areas of Antananarivo, Madagascar. BMC Infect Dis 2008 Feb;8:25.
41. Singh P, Kaur R, Kaur A. Frequency distribution of Hepatitis C virus in different geographical regions of Punjab: retrospective study from a tertiary care centre in North India. J Nat Sci Biol Med 2014 Jan;5(1):56-58.

42. Sandhu R, Dahiya S. Prevalence of anti-hepatitis $C$ virus antibodies among inpatients and outdoor attendees of a tertiary care institute. Br Biomed Bull 2015 Jan;3(1):8-14

43. Da Ros CT, Schmitt CdaS. Global epidemiology of sexually transmitted diseases. Asian J Androl 2008 Jan;10(1): 110-114.

44. Te HS, Jensen DM. Epidemiology of hepatitis B and C viruses: a global overview. Clin Liver Dis 2010 Feb;14(1):1-21. 